\title{
Active Learning Methods for Sustainable Education Development
}

\author{
Sarma Cakula $\mathrm{PhD}$ \\ Vidzeme University of Applied Sciences, Latvia \\ sarma.cakula@va.lv
}

\begin{abstract}
The growing importance of ICT in educational processes activates the development of modern electronic teaching aids in various content areas and the development of teaching methods. The integration of ICT must ensure the improvement of the teaching/learning environment and the development of new teaching/learning approaches. Students' motivation, engagement and interest in own learning are obligatory for successful and student-oriented education, especially in a situation of crisis, when educational institutions can immediately be closed after a governmental decision (pandemic caused by "Covid-19") as it happened in March, 2020. All teaching and learning had been moved unexpectedly to remote/distance education setting, to adapt the learning methods and processes and to motivate the learners contributes to sustainable education. The aim of the paper is to develop active learning methods in digital environment to modernize the learning environment required for STEM in Vidzeme University of Applied Sciences, which includes the development of teaching methods and tools and their suitability for the digital age. The methodology includes theoretical research and practical experiments for full time students in face-to-face and digital environment. There are three experimental groups for course "Algorithms and data structures" - one for traditional teaching, one with active learning methods faceto-face classroom and one with active learning methods in digital environment. Results of the research shows that active learning methods influence positively to course results but there are no differences for course results between groups with active learning methods in face-to-face and digital environment.
\end{abstract}

Keywords: active learning methods, digital environment, university education, learning sustainability.

\section{Introduction}

Transition processes in the global economy and politics are ongoing; these include education, research and culture. Creation and usage of information has grown very rapidly over the last years. People have experienced such phenomenon as information overload. Work equipment becomes more complex and sophisticated. Accordingly, this requires more skills and knowledge to operate them. It leads to acknowledge that knowledge has become a highly valued asset. The digital transformation of the global economy and society is increasing the complexity of the modern world, as well as the speed of change, due to increased connectivity and an increase in the number of better educated individuals worldwide. These two elements - complexity and speed of change - mean that connecting education to the trends shaping the world we live in has never been so urgent (OECD, 2015). A way of obtaining new knowledge and skills already has been seen for a while as an actual aspect of university education and it shows no sign of losing its importance. Modern education system has difficulties in copying traditional teaching methods with unforeseen learning outcomes in the digital age and todays information systems and technologies provides large amount continuous development of digital tools opening possibilities for strengthening education system.

The problem is the inefficient or incomplete utilization of active learning methods and cognition technologies and the non-usage of knowledge management technologies in the study process. The paper addresses the active pedagogical methods in changing now-day pedagogic paradigm improving all forms of active learning in various settings - learning in classroom, blended learning, and e-learning. The paper focuses on educational methods that enhance each individual's ability to acquire the knowledge, values and skills needed to participate in decision-making on individual or collective action at local and global levels to improve the quality of life without compromising the needs of future generations. Teaching materials and methods in the digital environment would ensure the rapid and secure introduction of new knowledge, as well as the mutually beneficial exchange of data and knowledge, which is the key to the sustainable provision of education. Active learning methods develop learners' ability to respond flexibly in a competitive environment. 
The aim of the paper is to develop active learning methods in digital environment to modernize the learning environment required for STEM (science, technology, engineering and math) in Vidzeme University of Applied Sciences. The paper leads to the development of a new approach to active learning in information technology, a tool to support methods and research into knowledge discovery from active learning user feedback data in support of the new learning methodology.

\section{Methodology}

Experiments on active learning methods were used in Algorithms and Data structures course and Statistics for Engineering for information technology bachelor students in Vidzeme University of Applied Sciences. To make experiments comparable and results generalizable, all cases are analysed according to a common methodology. Specifically, an extension of knowledge discovery based active learning feedback data for active learning methodology support in teaching and learning process. Implementing active learning methods in developing mobile applications via collective coding exercises in the classroom as a part of an active learning strategy and development exercises.

The main tasks of the paper include theoretical and experimental research of active learning methods in the digital environment, experimental testing and knowledge discovery from active learning user feedback data for active learning support. Students will become more adaptable in an ever-changing society characterised by higher visual literacy skills, great complexity, and technological advances learned by active learning methods.

Experiment includes learning through experience and active participation based on collective coding (by VIA student cods) exercises, quizzes, projects, and other approaches. Learning through experience in software development courses are carried out as practical tasks during collective exercises developing solutions. Work on software development exercises is performed in small groups with learning feedback data being regularly gathered in several ways to serve later as feed-in during the knowledge discovery process for active learning support. The teaching/learning methods will be explored in the experiment of three different groups of high practical value in Vidzeme university of Applied Sciences- one for traditional teaching, one with active learning methods face-to-face classroom and one with active learning methods in digital environment. There were 161 students participating in the experiment from 2016 -2020. Basic concept of research approach is shown in Figure 1.

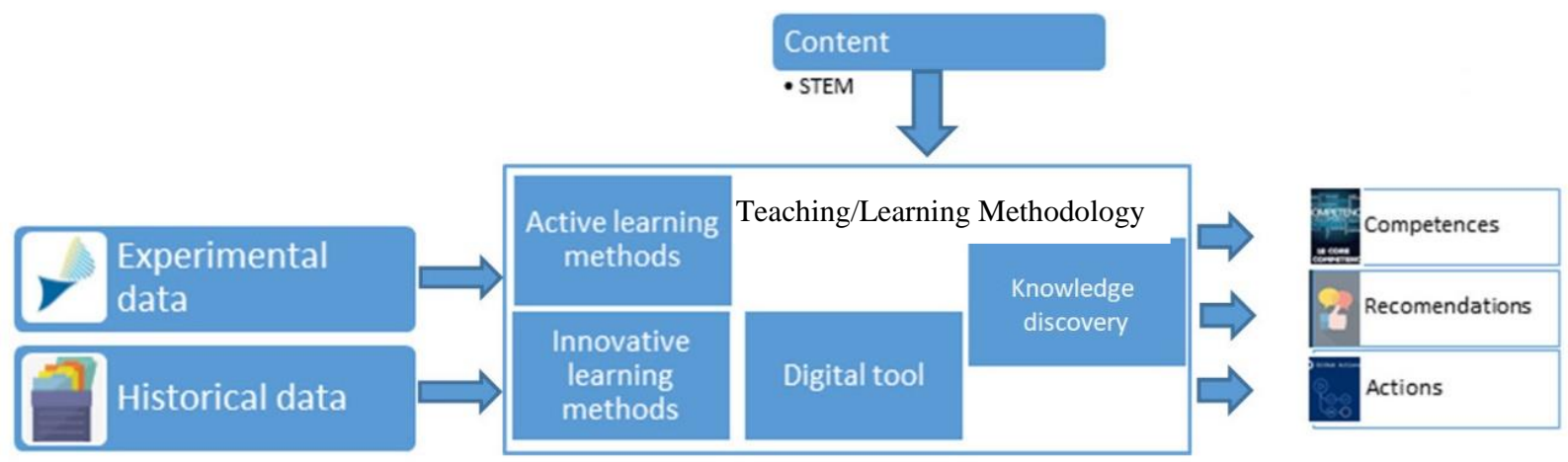

Figure1. The key concepts of the research approach.

As a content base was used Algorithm and data structure course for information technology students to develop active learning methods in digital environment for developing skills to solve complicate problems in STEM subjects, to teach students to choose the most optimal data structures and their algorithms and to use them in practice in the software development process.

The learning solutions will allow students better understand STEM subjects including the aspects of what makes this knowledge resilient.

The experiment involves developing active learning classroom methods in technology-enhanced learning environment, preparing and analysing tasks in different subject areas for visual and schematic presentation, innovative and visual thinking and development of digital competence. 
The traditional learning student group each face-to-face session contains lecture 1,5 hours and practical work 1,5 hours leading by professor solving different exercises. Course final grade combines from results of practical work, two tests, project work and exam.

Approach to study in both active learning groups is based on students' deep preparation for the next face-to-face or digital session 3 hours according to lectures schedule. All lecture materials in two different forms - presentation and video - should be studied before the session. Each session started with discussion about the topic clearing theory and debatable issues. After discussion students were used different active learning methods such as Dotmocracy, Fishbowl, Quescussion, Index Card Pass, Flipped Classroom, Complete Turn Taking, Respond, React, Reply, Round Table, Think-Pair-Share, Post It Parade including solving different exercises on an algorithm theory (Center of Excellence..., 2020, Flipped Classroom, 2020). Activity of each student were measured.

Course final grade combines from four activities - results in active learning methods, three tests, project work and exam. Feedback from students is considered.

\section{Theoretical background}

Learning is the cognitive process that we use to incorporate new information into our prior knowledge (Piaget, 1972; Carey, Zaitchik, Bascandziev, 2015). Learning occurs through very different things, such as eating a daily breakfast or walking through the woods that determine our behaviour or habits. Learning also occurs through socialization, where we gain new knowledge. Cognitive learning is the process of information processing that enters and changes our cognitive system (Cakula, Majore, 2019).

Students' motivation, engagement and interest in own learning are obligatory for successful and studentoriented education, especially in a situation of crisis, when educational institutions can immediately be closed after governmental decision (pandemic caused by "Covid-19") as it happened in March, 2020. All teaching and learning have been moved unexpectedly to remote/distance education settings, to adapt the learning methods and processes and to motivate the learners contributes to sustainable education. The trend of world education has shifted to a more explicit focus on "21st century skills" or transversal competencies (Care, 2017). The humanization, accessibility, openness and diversity of educational environment are the guarantee of the sustainable development of education. I. Katane, E. Katans and G. Vavere give a theoretical substantiation to the ideas of distance learning, what is related to the broadening of opportunities offered in connection to home education under home environment and international education or cross-border education (Katane, Katans, Vavere, 2012). Within this broad framework, education for sustainable development helps students examine and reflect upon their professional responsibilities, capabilities, and personal motivations (Mulà et al., 2017). Different orientations toward thinking about new technologies in education should be developed not just as tools or delivery systems, but as a set of resources and affordances that provide an opportunity to rethink our educational aims, methods, and institutions (Burbules, Fan, Repp, 2020). Technology-enhanced learning environments create flexibility and sustainability in education (Cakula, 2018). Active learning methods enable teacher- or student-generated new content (Kim et al., 2020). Despite concerns that the transition to distance learning could reduce pedagogical effectiveness, lectures remain the main teaching method in university classrooms. A. Shoufan has described his successful experience as working with students remotely in the MOODLE environment, using active learning methods in a digital logic design course in an electrical and computer engineering program, managing to ensure the full involvement of students. He supposes that today's learning technologies have the potential to make lectures as a method unnecessary by supporting student's active learning in the classroom (Shoufan, 2020).

M.P. Molina-Torres and R. Ortiz-Urbano suggest to use active-participatory method (Figure 1), aimed at transforming the role of the teacher in the direction of counselling and the increase of students' practical independent work role through their experience and critical thinking, as well as activating group activities that promote the development of responsibility-sharing skills (Molina-Torres, Ortiz-Urbano, 2020).

The outcome of feedback is information related to a task or process of learning that fills a gap between what is understood and what is aimed to be understood (Sadler, 1989). J. Hattie and H. Timperley proposed that feedback in higher education should answer three major milestones: defining what the goals are about, asking what progress is being made towards meeting the goals, and asking what activities need to be 
undertaken to achieve better student performance (Hattie, Timperley, 2007). B. Briede and L. Peks represent a constructivist view - refusing to pass information from the teacher to student, and emphasize the importance of self-experience and reflection, thus meaningfully developing their methodological competencies, students develop their ability to control their learning, improve learning skills and assess their learning outcomes (Briede, Peks, 2014). The traditional lecture assessment involves feedback limited to marks, grades, or scores, this type of feedback has turned out to be less effective than more descriptive feedback (Brown, Peterson, Yao, 2016), therefore it is reasonable to research and develop a knowledge discovery-based active learning feedback data solution. The author' research planned active learning feedback data solution is grounded and influenced by professors' previous research.

\begin{tabular}{ll}
\hline Traditional Method & Active-Participatory Method \\
\hline Passive and receptive students. & Active, constructive and critical student. \\
Individual and lone work. & Group and motivational work. \\
Transmissive teachers. & Teacher as guide and counsellor. \\
Individualism of the teaching staff. & Coordination of teaching teams. \\
Assessment limited to the final result. & Assessment of the process as an end in itself. \\
\hline
\end{tabular}

Figure 1. From the traditional model to the active participatory method

(Molina-Torres, Ortiz-Urbano, 2020).

Different types of digital learning technologies serving different types of learning will be applied in the pedagogical experiment (Table 1). These types will be combined to find the best possible combination of digital learning methods.

Table 1

Types of conventional and digital learning technologies (adapted from D. Laurillard (2012))

\begin{tabular}{|l|l|l|}
\hline $\begin{array}{c}\text { Learning } \\
\text { through }\end{array}$ & \multicolumn{1}{|c|}{ Conventional technology } & \multicolumn{1}{|c|}{ Digital technology } \\
\hline Acquisition & $\begin{array}{l}\text { Listening to teacher's explanation, } \\
\text { face-to-face discussion, reading books. }\end{array}$ & $\begin{array}{l}\text { Digital technology will be used for online classes, } \\
\text { watching animations/videos presented by the teacher. } \\
\text { Discussion in digital environment }\end{array}$ \\
\hline Inquiry & $\begin{array}{l}\text { Text-based study guides, various } \\
\text { resources suggested by the teacher. }\end{array}$ & $\begin{array}{l}\text { Online advice and guidance by the teacher, digital } \\
\text { tools to search for examples and solutions. }\end{array}$ \\
\hline Practice & $\begin{array}{l}\text { Practicing in the exercise book or } \\
\text { workbook, practicing on the } \\
\text { blackboard or whiteboard. }\end{array}$ & $\begin{array}{l}\text { Simulations, designed task-specific interactive } \\
\text { visual objects, online group work as assigned by the } \\
\text { teacher. }\end{array}$ \\
\hline Production & $\begin{array}{l}\text { Producing own solutions of exercises } \\
\text { (drawn by hand) and designs. }\end{array}$ & $\begin{array}{l}\text { Producing own solutions of exercises (drawn by } \\
\text { hand) and designs. }\end{array}$ \\
\hline Discussion & $\begin{array}{l}\text { Seminars, discussions in classroom, } \\
\text { online discussion forums. }\end{array}$ & $\begin{array}{l}\text { Discussion groups with shared online whiteboard, } \\
\text { asynchronous discussions on the algorithm tasks, } \\
\text { web-conferencing tools for online classes. }\end{array}$ \\
\hline Collaboration & $\begin{array}{l}\text { Working in pairs/small groups, using } \\
\text { different active learning methods }\end{array}$ & $\begin{array}{l}\text { Working in pairs/small groups, using online } \\
\text { technologically supported active learning methods } \\
\text { (forums, chat rooms, blogs, portfolios, wikis). }\end{array}$ \\
\hline
\end{tabular}

Nowadays, when Covid-19 pandemic and potential school lockdown is still actual, students in school might become less motivated and have difficulties in keeping their attention during the lessons, especially, if the topic is complicated or completely unfamiliar. Offering the study content in different learning forms enables higher level thinking and communication, using various systems of symbols, and develops visual literacy.

Digital visual literacy is one of the eight fields in digital competency, included in the European Competence Framework as one of the key competences for future citizens. However, technological literacies - digital reading and writing, information, and visual literacy - are primarily emphasized when talking about human functioning nowadays and in future. Traditionally educators have perceived text as the primary source of information, leaving images, diagrams, and schemes behind as less important. 
However, during the last decades it has been proven that visualisation is necessary in various subject areas. There is a large amount of visual information elements constantly competing for our attention every day and everywhere - outdoor advertisements, mobile applications. Nowadays it is not enough if a person is simply print literate - one should become acquainted with the multiple formats of information.

Reading skills are important for the ability to solve various tasks in school and life. However, if reading skills are lower, students might have difficulty to follow the instruction and are less able to acquire knowledge. Latvian students reading skills, according to OECD PISA 2018 results (OECD, 2018) were lower than OECD average.

Multimedia learning theory (Mayer, 2010) proposes that there are situations where spatial relations or complex imagery can't be described by words as efficiently as necessary, and pictures are the only illustration in the case. Educational learning materials and methods should not be mainly based on texts and reading. To promote sustainable solutions for active learning, alternative teaching methods should be introduced (Wong et al., 2017). Flipped classroom, think-pair-share, pro-con-grid and others are used in experimental courses.

However, during Covid-19 pandemic it was clear that distance learning management was very fragmented from the technology-enhanced learning point of view. It has been decided by the Ministry of Education and Science to develop a common technological platform for schools for teachers' and students' ease of use for planning lessons, assigning tasks and giving feedback (Plāno veidot vienotu..., 2020).

\section{Results and Discussions}

Statistical data analyses used for collected data shows that in all tests project work, exam and final grade normal distribution has formed with probability level $95 \%$ but not for activity in active learning (Table 2). The same situation is in each separate group. The mean is one of the main characteristics of the normal distribution therefore statistical t-tests will be used for evaluating course results.

There is a difference between traditional and active learning groups starting from the second test. The mean of Test1 for traditional 6.53, active learning classroom 6.58, digital active learning 6.23. Kolmogorov-Smirnov t-test for each two independent samples. The first test shows the same mean on probability level $95 \%$ for all three student groups. Active learning method is a new approach for students therefore they need time to adapt the new learning style.

Kolmogorov-Smirnov t-test mean for test2, test3, project, exam and final grade shows difference on probability level $95 \%$ between traditional learning and both active learning groups but there is not difference on probability level $95 \%$ between active learning classroom and digital active learning. The higher degrees are for students in digital active learning classrooms and students from active learning and only then traditional learning. For example, final grades for digital active learning mean are 7.26 and for active learning classroom 7.07, then comes students from traditional learning with mean 6.53.

Table 2

Results of One-Sample Kolmogorov-Smirnov Test for Normal Distribution.

\begin{tabular}{|c|c|c|c|c|c|c|c|}
\hline & & Test1 & Test2 & Project & Exam & Final & $\begin{array}{c}\text { Activity in active } \\
\text { learning }\end{array}$ \\
\hline $\mathrm{N}$ & & 161 & 160 & 157 & 161 & 161 & 100 \\
\hline \multirow{2}{*}{$\begin{array}{l}\text { Normal } \\
\text { Parameters }\end{array}$} & Mean & 6.37 & 6.13 & 7.76 & 6.40 & 7.08 & 1.87 \\
\hline & Std. Deviation & 1.43 & 1.53 & 1.59 & 1.80 & 1.08 & 2.77 \\
\hline \multirow{3}{*}{$\begin{array}{l}\text { Most } \\
\text { Extreme } \\
\text { Differences }\end{array}$} & Absolute & .20 & .13 & .19 & .10 & .07 & .36 \\
\hline & Positive & .09 & .13 & .14 & .10 & .07 & .36 \\
\hline & Negative & -.20 & -.09 & -.19 & -.09 & -.07 & -.25 \\
\hline \multicolumn{2}{|c|}{ Kolmogorov-Smirnov Z } & 1.21 & .79 & 1.15 & .61 & .41 & 2.19 \\
\hline \multicolumn{2}{|c|}{ Asymp. Sig. (2-tailed) } & .091 & .568 & .126 & .854 & .996 & .00 \\
\hline
\end{tabular}


There is also high correlation between activity in active learning and all course results (Table 3). The number of students is 100 , they are active learning students from both groups active learning classroom and digital active learning.

Students who are more active in the learning process reached better results during the course and in final grades. The highest correlation is between activity in active learning and exam 0.882 .

Table 3

Correlations in Active Learning

\begin{tabular}{lcccccc}
\hline & Test1 & Test2 & Project & Exam & Final & Activity in active learning \\
\hline Test1 & 1.000 & 0.460 & 0.575 & 0.521 & 0.678 & 0.529 \\
Test2 & 0.460 & 1.000 & 0.557 & 0.504 & 0.654 & 0.517 \\
Project & 0.575 & 0.557 & 1.000 & 0.725 & 0.762 & 0.611 \\
Exam & 0.521 & 0.504 & 0.725 & 1.000 & 0.835 & 0.882 \\
Final & 0.678 & 0.654 & 0.762 & .835 & 1.000 & 0.778 \\
Activity in active & 0.529 & 0.517 & 0.611 & 0.882 & 0.778 & 1.000 \\
learning & & & & & & \\
\hline
\end{tabular}

The question for discussion is about student feelings in all three groups. Students from traditional learning describe the study process for STEM subjects as very hard and teacher guidance is crucial. Students from active learning classrooms are more involved in the study process and cooperation with teachers. Students from digital active learning describe that they get tired faster than face-to-face classrooms and they need much more breaks during these $3 \mathrm{~h}$.

\section{Conclusions}

Focusing on nowadays pedagogical paradigms teaching and learning changes direction from "teacher to learner" to "learner to teacher". It means that student occurs in the system more actively and affect on the teaching methods and content. In the modern day, it is not possible to maintain sustainable competition in professional environment without improving practical skills and knowledge, which leads to increased popularity of active learning methods in education.

All forms of education, both full-time and part-time on place or remotely, are equally important and complement each other thus enriching culture of education, general experience of the learning individuals and broadening the learning environment of the individuals and the general public. Data statistical analyses also demonstrate the development of innovative learning methods and knowledge base extension.

The development of methods and available technologies increasingly affect development of sustainable society and determines tendencies in education thus changing the nature of further education.

Active learning methods in both: face-to-face and digital classroom strength of the results to be achieved.

\section{Acknowledgment}

Support for effective participation of Vidzeme University of Applied Sciences within the international scientific circles (ViA-lnt), project number 1.1.1.5/18///005

\section{Bibliography}

1. Briede B., Peks L. (2014). A constructivist approach in teaching in higher education for getting methodological and reflection competences. In V. Dislere (Ed.), The Proceedings of the International Scientific Conference Rural Environment. Education. Personality(REEP), 7. Jelgava: LLU, 84-89. Retrieved from: https://lufb.llu.lv/conference/REEP/2014/Latvia-UnivAgricult-REEP-2014proceedings-84-89.pdf

2. Brown G.T.L., Peterson E.R., Yao E.S. (2016). Student conceptions of feedback: Impact on self-regulation, self-efficacy, and academic achievement. British Journal of Educational Psychology, 86(4), 606-629. doi: 10.1111/bjep.12126 
3. Burbules N.C., Fan G., Repp P. (2020). Five trends of education and technology in a sustainable future. Geography and Sustainability, 1(2), 93-97. doi: 10.1016/j.geosus.2020.05.001

4. Cakula S. (2018). Smart Technological Learning Conceptual model. International journal of Engineering and Technology, 7(2.28), 152-156. doi: 10.14419/ijet.v7i2.28.12900

5. Cakula S., Majore G. (2019). Future Generation Education Technological Model. In the Proceedings of IEEE International Conference Intelligent Computing and Information Systems, (ICICIS) 9, 371-376. doi: 10.1109/ICICIS46948.2019.9014852

6. Care E. (2017). Global initiative around assessment of 21 st century skills. Retrieved from http://bangkok.unesco.org/content/global-initiative-around-assessment-21st-century-skills

7. Carey S., Zaitchik D., Bascandziev I. (2015). Theories of development: In dialog with Jean Piaget. Developmental Review, 38, 36-54. doi: 10.1016/j.dr.2015.07.003

8. Center of Excellence in Learning and Teaching. (2020). Stony Brook University. https://www.stonybrook.edu/celt/services/active_learning/index.php

9. Flipped Classroom. (2020). The University of Texas at Austin. https://facultyinnovate.utexas.edu/instructional-strategies/flipped-classroom

10. Hattie J., Timperley H. (2007). The Power of Feedback. Review of Educational Research, 77(1), 81-112. doi: 10.3102/003465430298487

11. Katane I., Katans E., Vavere G. (2012). Environment of distance learning for humanization and democratization of education: the historical aspect. In V. Dislere (Ed.), The Proceedings of the International Scientific Conference Rural Environment. Education. Personality (REEP), 5. Jelgava: LLU, 35-42. Retrieved from https://llufb.llu.lv/conference/REEP/2012/REEP-2012proceedings-E-ISSN-2255-808X.pdf\#page $=36$

12. Kim J., Hwang J., Chi S., Seo J.(2020). Towards database-free vision-based monitoring on construction sites: A deep active learning approach. Automation in Construction 120, doi: 10.1016/j.autcon.2020.103376

13. Laurillard D. (2012). Teaching as a Design Science. Building Pedagogical Patterns for Learning and Technology. New York and London: Routledge

14. Mayer R.E. (2010). Multimedia learning: Are we asking the right questions? Educational Psychologist, 32(1), 1-19. doi: 10.1207/s15326985ep3201_1

15. Molina-Torres M.P., Ortiz-Urbano R. (2020). Active Learning Methodologies in Teacher Training for Cultural Sustainability. Sustainability, 12(21), No. 9043. doi: 10.3390/su12219043

16. Mulà I., Tilbury D., Ryan A., Mader M., Dlouhá J., Mader C., Benayas J., Dlouhý J., Alba D. (2017). Catalysing change in higher education for sustainable development: A review of professional development initiatives for university educators. International Journal of Sustainability in Higher Education, 18(5) 798-820. doi: 10.1108/IJSHE-03-2017-0043

17. OECD. (2015). Students, computers and learning: Making the connection. Paris: OECD Publishing. doi: 10.1787/9789264239555-en

18. OECD. (2018). Programme for International Student Assessment (PISA). Results from PISA 2018. Retrieved from https://www.oecd.org/pisa/publications/PISA2018_CN_LVA.pdf

19. Piaget J. (1972). The Psychology of Intelligence. Totowa, NJ: Littlefield.

20. Plāno veidot vienotu "virtuālās klases" platformu [Plan to create a single "virtual classroom" platform]. (2020). Retrieved from https://www.lsm.lv/raksts/zinas/latvija/plano-veidot-vienotuvirtualas-klases-platformu.a362387 (in Latvian).

21. Sadler D.R. (1989). Formative assessment and the design of instructional systems. Instructional Science, 18, 119-144. doi: 10.1007/BF00117714

22. Shoufan A. (2020). Lecture-Free Classroom: Fully Active learning on Moodle. IEEE Transactions on Education, 63(4), 314-321. doi: 10.1109/TE.2020.2989921

23. Wong S.W.L., Miao H., Cheng R.W., Yip M.C.W. (2017). Graphic Novel Comprehension Among Learners with Differential Cognitive Styles and Reading Abilities. Reading \& Writing Quarterly, 33(5), 412-427. doi: 10.1080/10573569.2016.1216343 